\title{
PERTUMBUHAN DAN PERKEMBANGAN GONAD IKAN BAUNG (Hemibagrus nemurus) KETURUNAN G-1, G-2, DAN G-3
}

\author{
Irin Iriana Kusmini", Anang Hari Kristanto, Ani Widiyati, dan Fera Permata Putri \\ Balai Riset Perikanan Budidaya Air Tawar dan Penyuluhan Perikanan \\ Jl. Sempur No.1, Bogor 16129
}

(Naskah diterima: 16 September 2019; Revisi final: 15 November 2019; Disetujui publikasi: 18 November 2019)

\begin{abstract}
ABSTRAK
Ikan baung (Hemibagrus nemurus) telah berhasil didomestikasi oleh Balai Riset Perikanan Budidaya Air Tawar dan Penyuluhan Perikanan, Bogor. Hasil penelitian domestikasi, populasi Cirata memiliki fekunditas dan pertumbuhan yang lebih bagus, populasi ini dikembangkan hingga tiga generasi (G1, G2 dan G3) namun, ada informasi terbatas mengenai perbandingan antara perkembangan gonad dari berbagai generasi ikan. Tujuan penelitian ini adalah untuk mengukur pertumbuhan dan mengamati perkembangan gonad generasi pertama (G-1), kedua (G-2), dan ketiga (G-3). Parameter yang diukur dan diamati meliputi pengukuran panjang, berat, laju pertumbuhan spesifik, morfologi dan berat gonad, diameter oosit, dan indeks gonad somatik (IGS). Pengambilan sampel dilakukan setiap dua bulan dengan mengumpulkan sepuluh sampel ikan dari setiap generasi. Jaringan gonad disiapkan secara histologis dan diwarnai larutan asetokarmin sebagai zat pewarna. Pengamatan menggunakan mikroskop dengan perbesaran 4 x 10. Hasil penelitian menunjukkan bahwa pada usia 222 hari, gonad jantan dan betina secara fisik masih dalam bentuk benang halus. Namun, karakteristik sekunder pada ikan jantan seperti papila sudah mulai tampak meski tidak terlalu jelas. Pada usia 283 hari, ukuran oosit berkisar antara 0.025-0.05 mm. Pada usia 345 hari, telur mulai terlihat dengan ukuran oosit G-1, G-2, dan G-3 masing-masing berkisar antara $0.59 \pm 0.24,0.39 \pm$ 0.15 , dan $0.48 \pm 0.15 \mathrm{~mm}$. Setelah usia 406 hari, perkembangan gonad mencapai TKG-III dengan diameter rata-rata 0osit G-1, G-2, dan G-3 berkisar antara $1.13 \pm 0.11,0.92 \pm 0.18$, dan $1.11 \pm 0.10 \mathrm{~mm}$ dengan IGS dari G-1, G-2, dan G-3 dari 8.20\% $0.98 \%$ dan 4.8\% masing-masing. Tidak ada perbedaan yang signifikan antara diameter oosit G-1, G-2, dan G-3 ( $\mathrm{P} \leq 0,05)$. Keturunan kedua (G-2) merupakan generasi terbaik untuk dijadikan kandidat budidaya.
\end{abstract}

KATA KUNCl: ikan baung; Hemibagrus nemurus; umur; gonad; asetokarmine

ABSTRACT: Growth and gonadal development of Asian redtail catfish (Hemibagrus nemurus) G-1, G-2, and G3. By: Irin Iriana Kusmini, Anang Hari Kristanto, Ani Widiyati, and Fera Permata Putri

Asian redtail catfish (Hemibagrus nemurus) has been successfully domesticated by the Research Institutefor Freshwater Aquaculture and Fisheries Extension, Bogor. The results of the domestication of Cirata population have better fecundity and growth, this population has been developed for up to three generations (G1, G2 and G3) however, there is limited information regarding the comparison between the ovarian development of different generations of the fish]. This study's aim was to measure the growth and observe the ovarian development of the first (G-1), second (G-2), and third generations (G-3). The parameters measured and observed included the measurements of length, weight, specific growth rate, morphology and gonad weight, oocyte diameter, and somatic gonad index (IGS). The sampling was carried out every two months by collecting ten fish samples of each generation. Gonad tissues were histologically prepared and stained asetocarmine solution as the coloring agent. The observations used a microscope with a magnification of $4 \times 10$. The results of the study showed that at the age of 222 days, the maleand female gonads were physically still in the form of fine threads. However, secondary characteristics in male fish such as papillae have begun to appear though not very clear. At the age of 283 days, 00cytes' sizes ranged between $0.025-0.05 \mathrm{~mm}$. At the age of 345 days, the eggs were starting to be visible with the oocyte sizes of G-1, G-2, and G-3 ranged between $0.59 \pm 0.24$,

\footnotetext{
\# Korespondensi: Balai Riset Perikanan Budidaya Air Tawar dan Penyuluhan Perikanan. Jl. Sempur No.1, Bogor 16129, Indonesia.

Tel. + 622518313200

E-mail: putriferapermata@ yahoo.co.id
} 
$0.39 \pm 0.15$, and $0.48 \pm 0.15 \mathrm{~mm}$, respectively. After the age of 406 days, the development of gonads reached gonad maturating level III with the averagediameter of the oocytes of G-1, G-2, and G-3 ranged between $1.13 \pm 0.11$, $0.92 \pm 0.18$, and $1.11 \pm 0.10 \mathrm{~mm}$ with the IGS of G-1, G-2, and G-3 of $8.20 \% 0.98 \%$ and $4.8 \%$ respectively. There was no significant difference among the oocyte diameters of $\mathrm{G}-1, \mathrm{G}-2$, and $\mathrm{G}-3(\mathrm{P} \leq 0.05)$. The 2 nd generation (G2) is the best generation to be a candidate aquaculture.

\section{KEYWORDS: Asian redtail catfish; Hemibagrus nemurus; ages; ovarian; acetocarmine}

\section{PENDAHULUAN}

Ikan baung (H. nemurus) merupakan salah satu komoditas ikan air tawar ekonomis di Indonesia serta di wilayah Asia Tenggara. Ikan ini memiliki kualitas daging yang baik, sehingga harga cukup tinggi dibandingkan dengan jenis ikan air tawar lainnya (Handoyo et al., 2010). Berdasarkan info pasar dari (Farmbos, 2019; Hewan, 2019) harga ikan baung berkisar Rp47.000,00-Rp70.000,00 per kilogram, sedangkan ikan sejenis lainnya yaitu ikan lele harga berkisar Rp23.000,00-Rp26.000,00 per kilogram. Ikan baung juga memiliki kandungan protein, vitamin, dan asam lemak omega-3 yang baik untuk tubuh (Mesomya et al., 2002). Namun komersialisasi dan budidaya intensif terhadap spesies ini masih terbatas, karena sulitnya untuk berkembang biak secara alamiah di tempat penangkaran. Penyediaan benih untuk pembesaran sebagian besar masih mengandalkan tangkapan dari alam. Tujuan budidaya adalah untuk peningkatan produksi dan efisiensi (Nugroho et al., 2003). Oleh sebab itu, agar produksi dapat dilakukan secara optimal dan sesuai harapan maka dibutuhkan induk-induk yang berkualitas baik dan bagus untuk dikembangkan supaya dapat menghasilkan gonad yang berkualitas. Salah satu upaya untuk memperoleh induk yang berkualitas adalah dengan perbaikan plasma nutfah melalui program pemuliaan. Dengan program ini diharapkan dapat menciptakan generasi baru yang dapat tumbuh dan berkembang dengan cepat, serta dapat menghasilkan telur dalam jumlah yang lebih banyak.

Berdasarkan hal tersebut sebagai tindak lanjut perbaikan mutu genetik untuk meningkatkan produktivitas ikan baung, Balai Riset Perikanan Budidaya Air Tawar dan Penyuluhan Perikanan (BRPBTPP) Bogor, telah melalukan domestikasi dan beberapa penelitian tentang ikan baung termasuk keragaan bioreproduksi dan pertumbuhan tiga po pulasi ikan baung yaitu po pulasi Cisadane, Cirata, dan Serayu (Subagja et al., 2015). Dari hasil penelitian domestikasi ikan baung tersebut dinyatakan bahwa, populasi Cirata memiliki fekunditas dan pertumbuhan yang lebih bagus, sehingga populasi ini dikembangkan hingga tiga generasi (G-1, G-2, dan G-3). Pengetahuan tentang bioreproduksi ikan merupakan hal yang sangat penting dan mendasar untuk dipelajari sebelum menentukan pilihan terhadap komoditas yang akan dikembangkan.
Dalam hal ini organ yang memegang peranan terpenting dalam reproduksi adalah gonad. Menurut Selman \& Wallace (1989), ada tiga jenis perkembangan gonad seperti asynchronous, berbagai tahap perkembangan oosit ditemukan di gonad; group synchronous, setidaknya ada dua populasi perkembangan oosit ditemukan di ovarium atau synchronous, semua o osit berada dalam tahap perkembangan yang sama.

Gonad ikan mengalami beberapa tahapan perkembangan mulai dari pertumbuhan gonad, perkembangan, dan pematangan (maturasi). Pada dasarnya setiap spesies ikan mengalami tahapan yang sama dalam proses pertumbuhan dan perkembangan gonad, namun tidak semua spesies ikan mengalami tingkat kematangan gonad pada umur yang sama. Berdasarkan SK rilis varietas unggul Kementerian Kelautan dan Perikanan (KEPMEN-KP, 2015) ikan lele Mutiara pertama kali matang gonad pada umur lima bulan dan ikan mas Rajadanu pertama kali matang gonad umur 12 bulan (KEPMEN-KP, 2016). Studi mengenai perkembangan gonad ini dilakukan bertujuan untuk mendapatkan informasi mengenai tahapan perkembangan gonad, jenis perkembangan gonad, serta untuk mengetahui umur pertama kali matang gonad dari ketiga generasi ikan baung hasil pemulian. Melalui studi ini kita dapat mengevaluasi hasil akhir program pemuliaan khususnya terhadap perkembangan organ reproduksi ketiga generasi ikan baung, yang nantinya diharapkan dapat memberikan dampak positif terhadap produktivitasnya.

\section{BAHAN DAN METODE}

\section{Ikan Percobaan dan Pemeliharaan}

Ikan baung ( $H$. nemurus) yang digunakan pada percobaan ini berasal dari hasil domestikasi strain Cirata yang dilakukan oleh Balai Riset Perikanan Budidaya Air Tawar dan Penyuluhan Perikanan. Penggunaan populasi Cirata diharapkan akan meningkatkan produktivitas benih ikan baung yang dihasilkan, sebab berdasarkan penelitian (Subagja et al., 2015) ikan baung asal Cirata menghasilkan indeks ova somatik tertinggi yaitu $20,7 \%$ serta produksi spermatozoa sebelum dilakukan pengenceran berkisar antara 0,3 mL sampai 0,4 mL. Untuk memperoleh usia benih yang sama dari setiap keturunan induk G-0, G-1, dan G-2 dipijahkan secara buatan dalam waktu 
bersamaan dengan bantuan induksi hormon $\mathrm{GnRH}$ analog. Selanjutnya benih hasil pemijahan dipelihara dalam wadah dan lingkungan pemeliharaan yang sama. Selama pemeliharaan ikan diberi pakan komersial dengan kadar protein 34\% frekuensi pemberian pakan dua kali sehari yaitu pada pagi dan sore hari secara at satiation. Untuk melihat perkembangan gonad, pada umur 222 hari dilakukan ploting dan sampling pertama. Ikan dipelihara dalam tiga unit kolam semi permanen yang berukuran $5 \mathrm{~m} \times 8 \mathrm{~m} \times 1 \mathrm{~m}$, supaya dapat ditempati oleh tiga keturunan maka kolam tersebut disekat menjadi tiga bagian dengan menggunakan waring. Masing-masing kolam ditempati oleh setiap keturunan, penempatan ikan dilakukan secara acak dengan padat tebar 10 ekor per $\mathrm{m}^{-1}$. Pengambilan ikan saat ploting dilakukan secara acak dari setiap keturunan. Untuk mengetahui pertumbuhan masingmasing keturunan setiap dua bulan sekali dilakukan pengambilan data pertumbuhan. Parameter yang diukur meliputi pertambahan panjang, bobot, dan laju pertumbuhan spesifik (SGR). Parameter tersebut dihitung menggunakan rumus menurut Effendie (1979) dan Murtidjo (2001), sebagai berikut:

Pertambahan panjang mutlak:

$$
\mathrm{P}=\mathrm{Pt}-\mathrm{Po}
$$

di mana:

$\mathrm{P} \quad=$ pertumbuhan panjang mutlak $(\mathrm{cm})$

$\mathrm{Pt}=$ panjang akhir ikan hari ke-t $(\mathrm{cm})$

Po $=$ panjang awal ikan $(\mathrm{cm})$

Pertumbuhan bobot/biomassa mutlak:

$$
\mathrm{W}=\mathrm{Wt}-\mathrm{Wo}_{0}
$$

di mana:

$W=$ pertumbuhan bobot/biomassa mutlak (g)

$\mathrm{Wt}=$ bobot/biomassa akhir ikan hari ke-t $(\mathrm{g})$

$W_{0}=$ bobot/biomassa awal ikan (g)

Laju pertumbuhan spesifik (Weatherley \& Gill, 1987):

$$
\mathrm{SGR}=\left[\frac{\left(\ln W \mathrm{t}-\ln \mathrm{Wo}_{0}\right)}{\mathrm{t}}\right] \times 100 \%
$$

di mana:

SGR $=$ specific growth rate (laju pertumbuhan spesifik) $(\%$

$W t=$ bobot akhir rata-rata ikan hari ke-t (g/ekor)

$W_{0}=$ bobot awal rata-rata ikan (g/ekor)

$\mathrm{t}=$ hari

Indeks kematangan gonad:

$$
\text { IGS }=\frac{\mathrm{Bg}}{\mathrm{Bt}} \times 100 \%
$$

di mana:

IGS = indeks gonad somatik

$\mathrm{Bg}=$ bobot gonad

$\mathrm{Bt}=$ bobotikan

\section{Pengamatan dan Pembuatan Preparat}

Untuk mengetahui pertumbuhan dan perkembangan gonad ikan, pada umur 222 hari dilakukan sampling pertama dengan mengambil 10 ekor ikan sampel setiap generasinya. Secara visual pada usia ini ikan belum dapat dibedakan antara jantan dan betina, hal ini disebabkan karena belum munculnya ciri-ciri sekunder yang dapat membedakan antara keduanya. Sampling diawali dengan penimbangan bobot dan pengukuran panjang ikan. Untuk mengetahui pertumbuhan dan perkembangan gonad dilakukan pembedahan terhadap ikan sampel, lalu dilakukan pengambilan organ gonad untuk dijadikan preparat. Pembuatan preparat dilakukan dengan cara pencacahan organ gonad yang kemudian diberi pewarnaan dengan menggunakan larutan asetokarmin. Pembuatan larutan asetokarmin dapat dilakukan dengan cara melarutkan $0,6 \mathrm{~g}$ bubuk carmine ke dalam $100 \mathrm{~mL}$ asam asetat 45\% Kemudian Iarutan ini dipanaskan 2-4 menit (Kurniasih et al., 2006), setelah dingin dilakukan penyaringan dan disimpan dalam botol. Pengamatan preparat gonad ikan dilakukan dengan menggunakan mikroskop pada pembesaran 4 × 10. Pada usia 345 hari pengecekan perkembangan gonad sudah dapat dilakukan dengan menggunakan kanulasi ukuran 2,75 $\mathrm{mm}$; oleh sebab itu, untuk mengurangi kematian ikan sampel pengecekan gonad dilakukan tanpa pembedahan cukup dengan menggunakan kanulasi. Sel telur yang diperoleh dari hasil kanulasi, diameternya diukur dengan menggunakan mikrometer okuler yang ada pada mikroskop dengan pembesaran $4 \times 10$. Untuk memudahkan dan mengurangi risiko saat pengambilan sampel telur, ikan terlebih dahulu dibius. Selanjutnya sampel telur diambil minimal sebanyak 20 butir setiap ikan sampel.

\section{Analisis Data}

Untuk memudahkan dalam menganalisis data pertumbuhan dan distribusi dan diameter oosit, nilai rata-rata yang diperoleh ditabulasi kemudian dianalisis dengan menggunakan program One Way Analysis of Variance (ANOVA) SPSS-16 dan uji lanjut Duncan's, dengan tingkat signifikan $\mathrm{P}<0,05$.

\section{HASIL DAN BAHASAN}

\section{Pertumbuhan}

Pada akhir penelitian tidak terdapat perbedaan pertumbuhan yang signifikan antara ketiga keturunan 

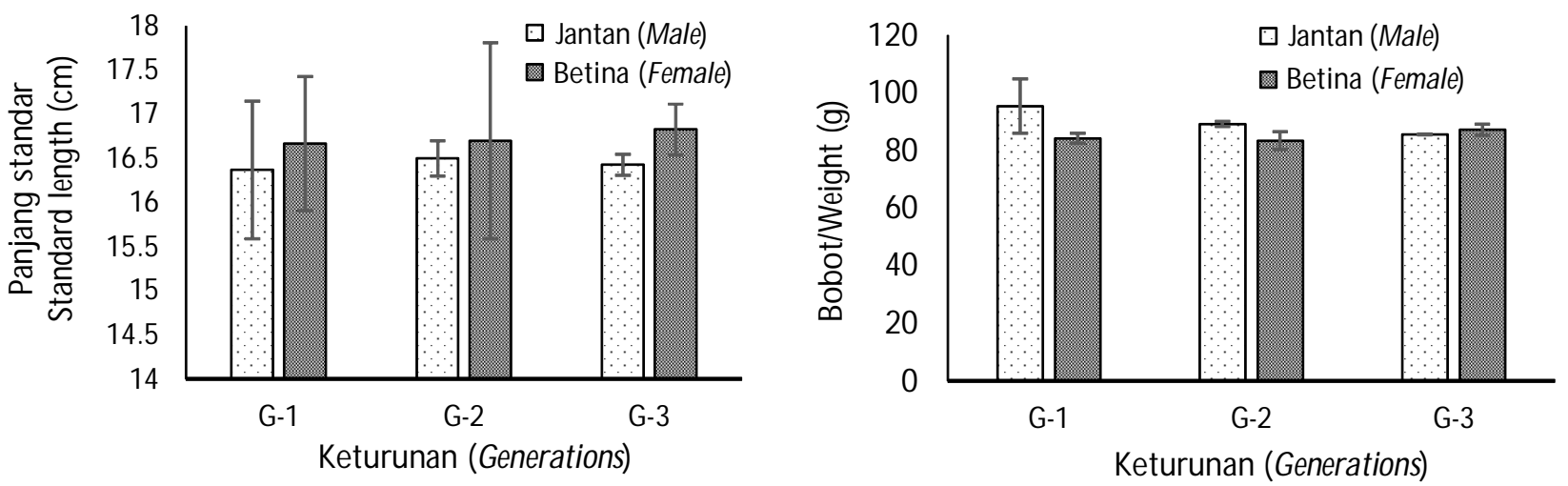

Gambar 1. Pertumbuhan panjang standar dan bobot ikan baung (H. nemurus) tiga keturunan pada umur 222 hari.

Figure 1. Growth standard length and weights of three generations Asian redtail catfish (H. nemurus) at 222 days old.
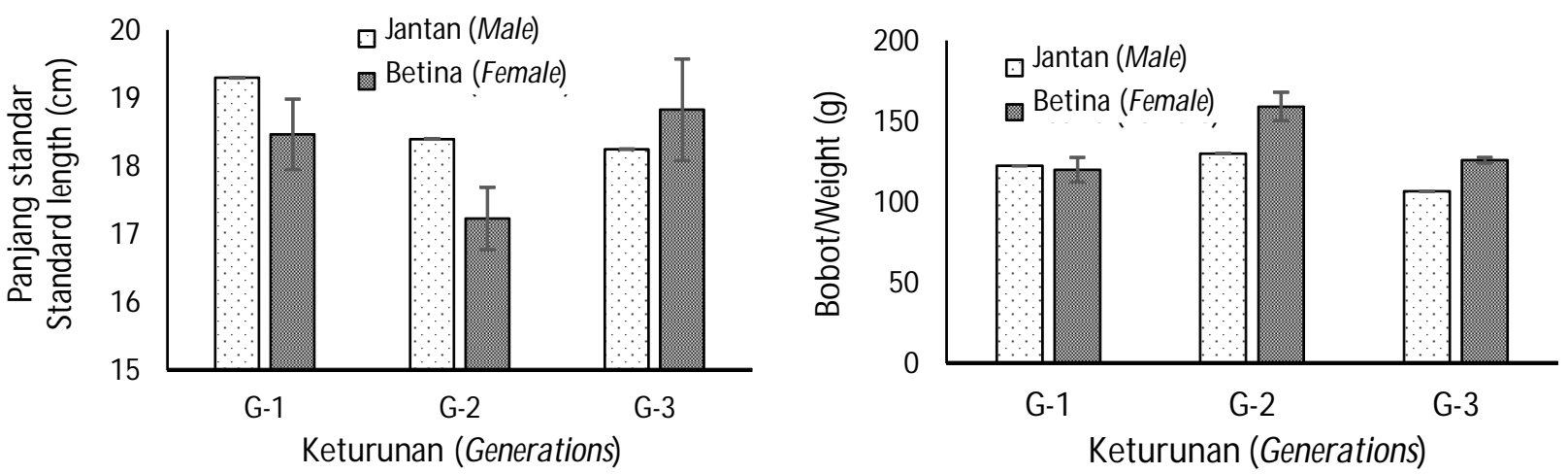

Gambar 2. Pertumbuhan panjang standar dan bobot ikan baung (H. nemurus) tiga keturunan pada umur 283 hari.

Figure 2. Growth standard length and weights of three generations Asian redtail catfish (H. nemurus) at 283 days old.
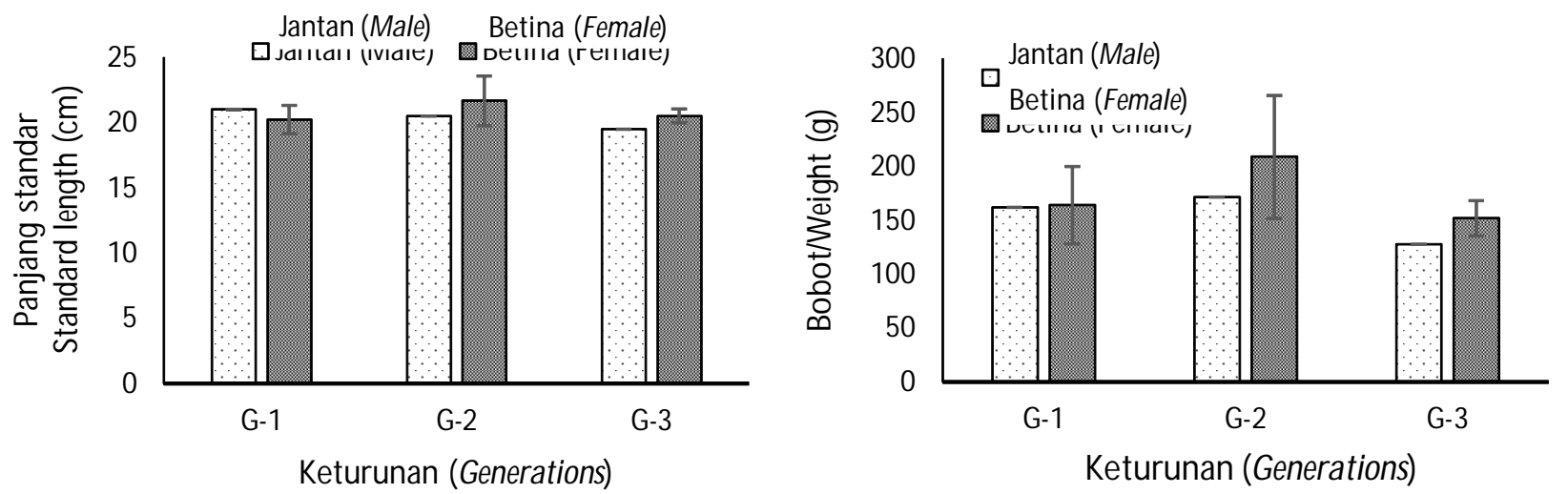

Gambar 3. Pertumbuhan panjang standar dan bobot ikan baung (H. nemurus) tiga keturunan pada umur 345 hari.

Figure 3. Growth standard length and weights of three generations Asian redtail catfish (H. nemurus) at 345 days old. 

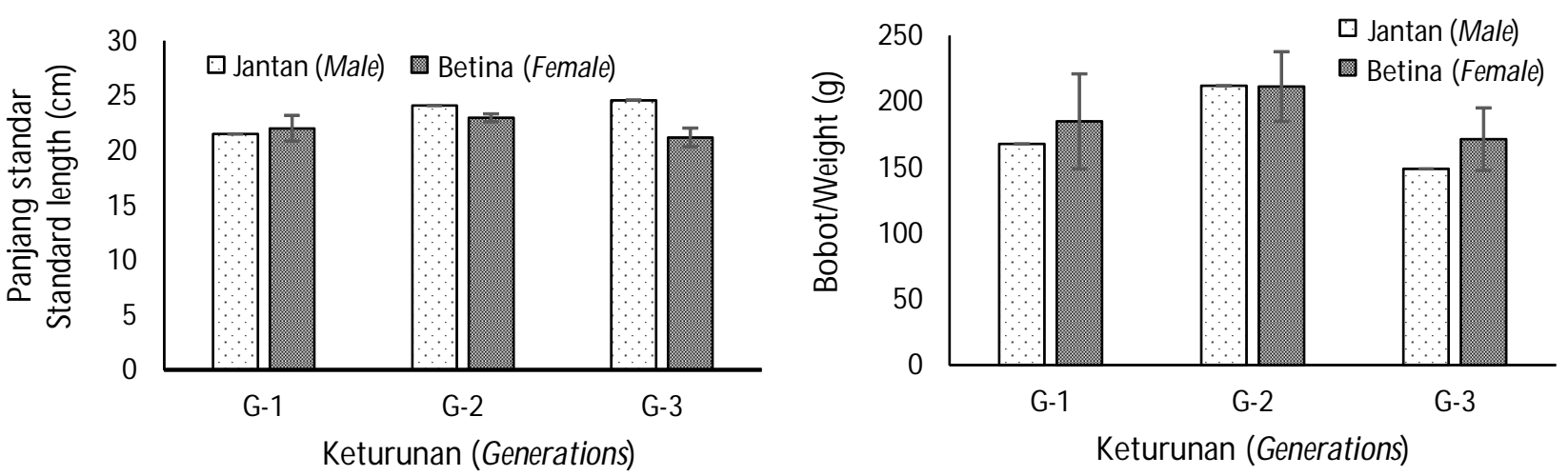

Gambar 4. Pertumbuhan panjang standar dan bobot ikan baung (H. nemurus) tiga keturunan pada umur 406 hari.

Figure 4. Growth standard length and weights of three generations Asian redtail catfish (H. nemurus) at 406 days old.

(Gambar 1, 2, 3, dan 4); namun jika dilihat dari bobot mutlak antara G-2 jantan lebih besar 74,13\%dari G-1, G-2 jantan lebih besar $93,87 \%$ dari G-3 jantan. Demikian halnya dengan pertumbuhan panjang, G-3 lebih besar 6,94\%dari G-2 dan 59,09\%dari G-1. Bobot mutlak keturunan G-2 betina lebih besar 27,05\%dari G-1 dan 52,18\% dari G-3, untuk panjang mutlak G-2 lebih besar 9,94\%dari G-1 dan 38,28\% G-3 (Tabel 1 dan 2). Dari data di atas jelas bahwa program pemuliaan membawa dampak positif salah satunya terhadap pertumbuhan, hal ini membuktikan telah terjadi perbaikan mutu genetik pada keturunan tertentu. Keadaan ini didukung oleh pendapat Effendie
(1979) bahwa pertumbuhan dapat dipengaruhi oleh genetik dan seks.

Dari Gambar 1 sampai dengan Gambar 4 terlihat bahwa pertumbuhan G-2 lebih baik dari dua keturunan yang lain. Ini menunjukkan bahwa pertumbuhan sel somatik G-2 jantan maupun betina berkembang lebih pesat.

\section{Morfologi Gonad Betina dan Jantan}

Morfologi, ukuran, dan volume gonad ikan baung ( $H$. nemurus) tumbuh dan berkembang seiring dengan pertambahan umur dan ukuran ikan, semakin

Tabel 1. Pertumbuhan mutlak dan laju pertumbuhan spesifik ikan jantan

Table 1. Absolute growth and specific growth rate male

\begin{tabular}{ccccc}
\hline \multirow{2}{*}{$\begin{array}{c}\text { Keturunan } \\
\text { Generations }\end{array}$} & $\begin{array}{c}\text { Panjang mutlak } \\
\text { Absolute length }\end{array}$ & $\begin{array}{c}\text { Laju pertumbuhan spesifik } \\
\text { Specific growth rate }\end{array}$ & $\begin{array}{c}\text { Bobot mutlak } \\
\text { Absolute weight }\end{array}$ & $\begin{array}{c}\text { Laju pertum buhan spesifik } \\
\text { Specific growth rate }\end{array}$ \\
\hline G-1 & $5.13 \pm 0.78$ & $0.80 \pm 0.08$ & $70.53 \pm 11.45$ & $0.31 \pm 0.07$ \\
G-2 & $7.6 \pm 0.2$ & $0.64 \pm 0.01$ & $122.82 \pm 0.91$ & $0.48 \pm 0.01$ \\
G-3 & $8.17 \pm 0.12$ & $0.61 \pm 0.01$ & $63.35 \pm 4.44$ & $0.03 \pm 0.03$ \\
\hline
\end{tabular}

Tabel 2. Pertumbuhan mutlak dan laju pertumbuhan spesifik Ikan Jantan

Table 2. Absolute growth and specific growth rate female

\begin{tabular}{|c|c|c|c|c|}
\hline \multirow{2}{*}{$\begin{array}{l}\text { Keturunan } \\
\text { Generations }\end{array}$} & \multicolumn{4}{|c|}{ Ikan betina (Female) } \\
\hline & $\begin{array}{l}\text { Panjang mutlak } \\
\text { Absolute length }\end{array}$ & $\begin{array}{l}\text { Laju pertumbuhan spesifik } \\
\text { Specific growth rate }\end{array}$ & $\begin{array}{l}\text { Bobot mutlak } \\
\text { Absolute weight }\end{array}$ & $\begin{array}{l}\text { Laju pertumbuhan spesifik } \\
\text { Specific growth rate }\end{array}$ \\
\hline G-1 & $5.37 \pm 1.90$ & $0.15 \pm 0.05$ & $100.96 \pm 37.07$ & $0.43 \pm 0.11$ \\
\hline G-2 & $5.9 \pm 1.13$ & $0.17 \pm 0.04$ & $128.26 \pm 34.22$ & $0.52 \pm 0.12$ \\
\hline G-3 & $4.27 \pm 0.06$ & $0.13 \pm 0.01$ & $84.28 \pm 23.04$ & $0.07 \pm 0.07$ \\
\hline
\end{tabular}




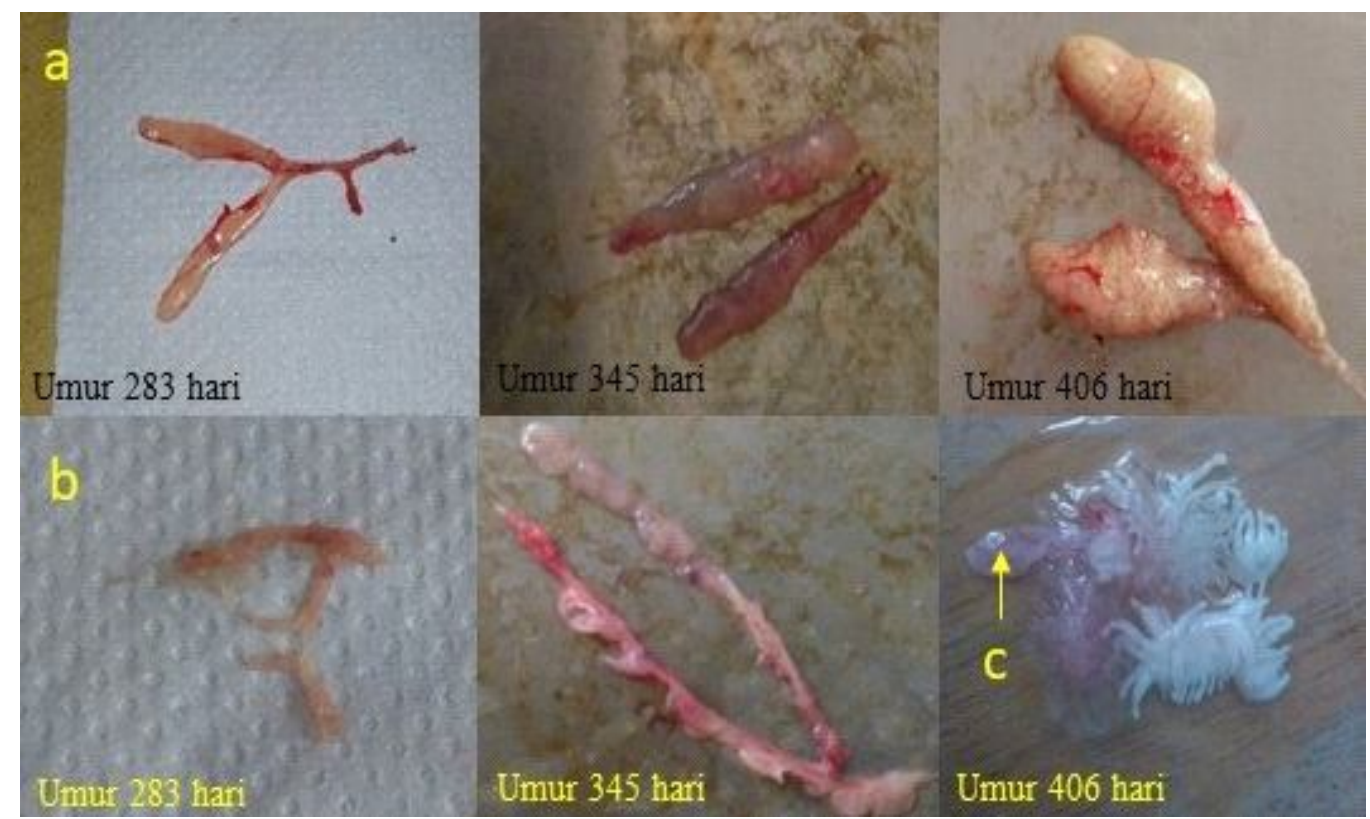

Gambar 5. Morfologi gonad ikan baung (H. nemurus) generasi G-3; betina (a), gonad jantan (b), dan kantung kemih (c).

Figure 5. Ovarian morphology of Asian redtail catfish (H. nemurus) G-3 generation; female (a), male (b), and bladder (c).

mendekati masa maturasi morfologi gonad terlihat semakin pejal dan bergerundul yang disertai dengan pertambahan ukuran gonad. Dilihat dari bentuk fisik gonad ikan jantan dan betina pada usia yang sama terlihat bahwa gonad ikan jantan lebih cepat berkembang dibanding gonad betina (Gambar 5), hal ini berlaku untuk ketiga generasi ikan baung. Kondisi ini dapat menerangkan bahwa pertumbuhan ikan jantan lebih cepat diawal; namun setelah itu, pertumbuhan akan melambat disebabkan nutrisi yang terserap dari pakan akan terfokus untuk perkembangan gonad sementara ikan betina dapat tumbuh lebih besar.
Berdasarkan pengamatan terhadap morfologi gonad ikan baung, gonad betina memiliki bentuk dan posisi yang mirip dengan jenis ikan bertulang sejati lainnya. (Molen \& Matallanas, 2004; Ravaglia \& Maggese, 2003; Koç et al., 2008) mengatakan bahwa perkembangan gonad ikan baung mirip dengan ikan teleostei pada umumnya. Morfologi gonad betina berbeda dengan ikan jantan, morfologi gonad ikan jantan lebih spesifik, gonad ikan jantan berbentuk gerigi, dan lembaran yang meruncing ke bagian posterior. Posisi gonad jantan dan betina menempel pada dinding rongga perut bagian atas di bawah tulang

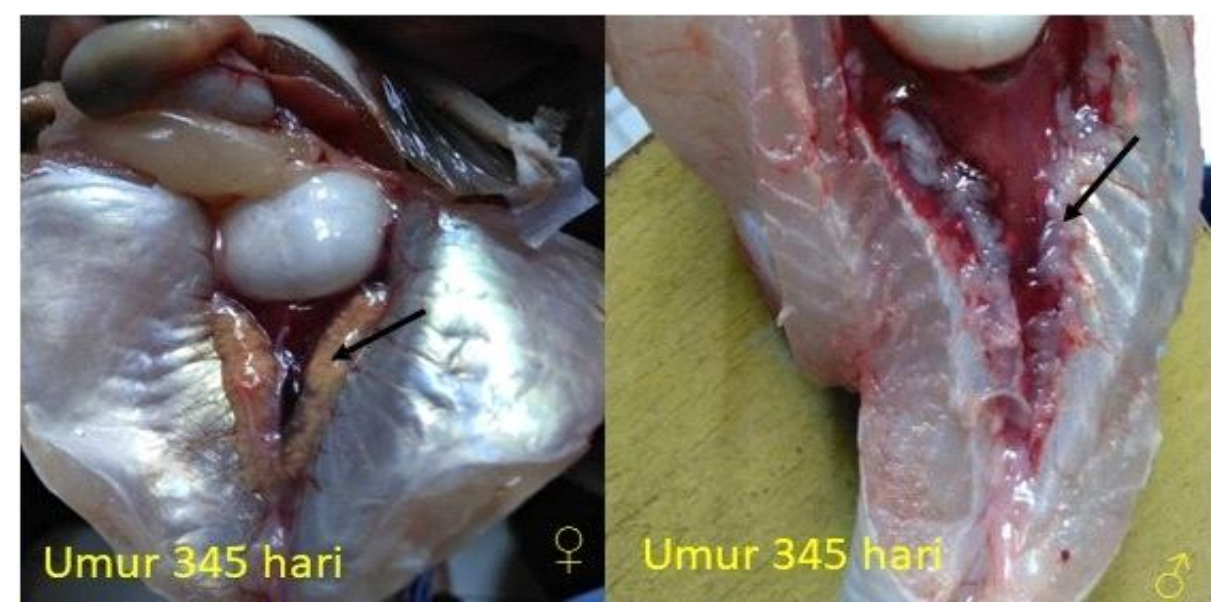

Gambar 6. Posisi gonad dalam rongga tubuh ikan baung (H. nemurus).

Figure 6. Gonad position in body cavity of Asian redtail catfish (H. nemurus). 
dorsal, yang dihubungkan oleh mesenterium dorsal dan terbentang dari anterior ke posterior (Gambar 6).

Pengamatan morfologi dan preparat histologi gonad G-1, G-2, dan G-3 dimulai dari umur 222-406 hari, dalam rentang waktu tersebut ditemukan empat tahapan perkembangan gonad ikan. Tahap awal pertumbuhan pada usia 222 hari, gonad terlihat seperti benang lurus yang sangat tipis dan sulit diambil. Pada tahap ini material gonad masih berupa gel yang akan menjadi cikal bakal oosit bagi ikan betina dan spermatozoid bagi ikan jantan. Sejalan dengan pertambahan umur, gonad betina dan jantan terus tumbuh memperlihatkan ciri fisik yang semakin nyata seperti, butiran halus yang tidak kasa mata dan sangat beragam, butiran yang sudah teridentifikasi dengan jelas, serta semakin seragamnya ukuran oosit, bentuk semakin fleksibel, serta permukaan gonad semakin bersih dari pembuluh darah. Perubahan morfologi tersebut diiringi dengan peningkatan fase perkembangan gonad (Tabel 3) dan (Gambar 7).

Hasil penelitian ini merujuk pada Ravaglia \& Maggese (2002); Koç et al., (2008); Krejszeff et al. (2009) yang mengatakan bahwa pada dasarnya perkembangan oosit terdiri atas empat tahap, namun dari beberapa tulisan dijelaskan Cek et al. (2001) dan Coward \& Bromage (1998) bahwa pertumbuhan gonad ikan baung dibagi menjadi tiga tahap yaitu pertumbuhan dasar, menengah, dan pematangan; sedangkan menurut Solomon \& Ramnarine (2007) perkembangan gonad ikan dilalui oleh enam tahapan. Meskipun antar generasi berada dalam umur dan lingkungan pemeliharaan yang sama, namun tidak

Tabel 3. Tingkat kematangan gonad ikan baung (H. nemurus) betina dan jantan berdasarkan ciri morfologis Table 3. Ovarian maturity of Asian redtail catfish (H. nemurus) male and female based on morphology characteristics

\begin{tabular}{|c|c|c|}
\hline $\begin{array}{l}\text { Tingkat kematangan } \\
\text { gonad (TKG) } \\
\text { Gonadal maturity level }\end{array}$ & $\begin{array}{l}\text { Betina } \\
\text { Female }\end{array}$ & $\begin{array}{c}\text { Jantan } \\
\text { Male }\end{array}$ \\
\hline I & $\begin{array}{l}\text { Bentuk gonad seperti benang lurus dan jika membran } \\
\text { dilepas gonad masih berupa gel, butiran telur belum } \\
\text { dapat dibedakan } \\
\text { The gonad is shaped like a straight thread and if the } \\
\text { membrane is removed the gonad is still in the form of } \\
\text { a gel, the egg granules cannot be distinguished }\end{array}$ & $\begin{array}{l}\text { Testes seperti benang lurus yang menempel } \\
\text { pada dinding rongga tubuh, warna putih susu } \\
\text { Testes are like straight threads that stick to the } \\
\text { walls of the body cavity, the color of milky white }\end{array}$ \\
\hline II & $\begin{array}{l}\text { Oosit masih menyatu dan belum dapat dipisahkan } \\
\text { antara satu dengan yang lainnya dan ukuran diameter } \\
\text { sangat bervariasi } \\
\text { Oocytes are still united and cannot be separated from } \\
\text { one another and the size of the diameter varies greatly }\end{array}$ & $\begin{array}{l}\text { Ukuran testes lebih besar, bentuk lebih jelas dari } \\
\text { TKG-I. Mulai terlihat ujung-ujung posterior } \\
\text { The size of the testes is larger, the shape is clearer } \\
\text { than TKG-I. Beginning to see the posterior endus }\end{array}$ \\
\hline III & $\begin{array}{l}\text { Ukuran lebih besar, pada bagian anterior melebar dan } \\
\text { bagian posterior meruncing, oosit sudah dapat } \\
\text { dipisahkan satu dengan yang lainnya. Inti sel sudah } \\
\text { terlihat pada bagian sentral. Pada permukaan gonad } \\
\text { masih banyak tampak pembuluh darah } \\
\text { Larger size, the anterior region widens and the } \\
\text { posterior part is tapered, oocytes can be separated } \\
\text { from one another. The cell nucleus is already visible in } \\
\text { the central part. On the surface of the gonad there are } \\
\text { still many blood vessels }\end{array}$ & $\begin{array}{c}\text { Ukuran testes semakin besar, berwarna putih } \\
\text { kekuningan dan lebih jelas dibanding TKG-II. } \\
\text { Permukaan gonad tidak rata, ujung posterior } \\
\text { bergerigi } \\
\text { The size of the testes is getting bigger, yellowish } \\
\text { white and clearer than TKG-II. Gonadal surface is } \\
\text { uneven, jagged posterior and }\end{array}$ \\
\hline IV & $\begin{array}{c}\text { Diameter telur semakin besar dan jelas terlihat di } \\
\text { bawah mikroskop. Bentuk telur lebih fleksibel dan } \\
\text { lebih bersih. Posisi inti sudah berpindah dari sentral } \\
\text { The diameter of the egg is getting bigger and is clearly } \\
\text { visible under a microscope. Egg shape is more flexible } \\
\text { and cleaner. The core position has moved from the } \\
\text { Central }\end{array}$ & $\begin{array}{c}\text { Ukuran testes besar, warna testes putih, pejal, } \\
\text { dan gerigi semakin besar. Panjang gonad sekitar } \\
\text { 3/4 dari panjang rongga perut } \\
\text { The size of the testes is large, the color of the white } \\
\text { testes, solid and serrated is getting bigger. } \\
\text { Gonadal length about } 3 / 4 \text { of the length of the } \\
\text { abdominal cavity }\end{array}$ \\
\hline
\end{tabular}




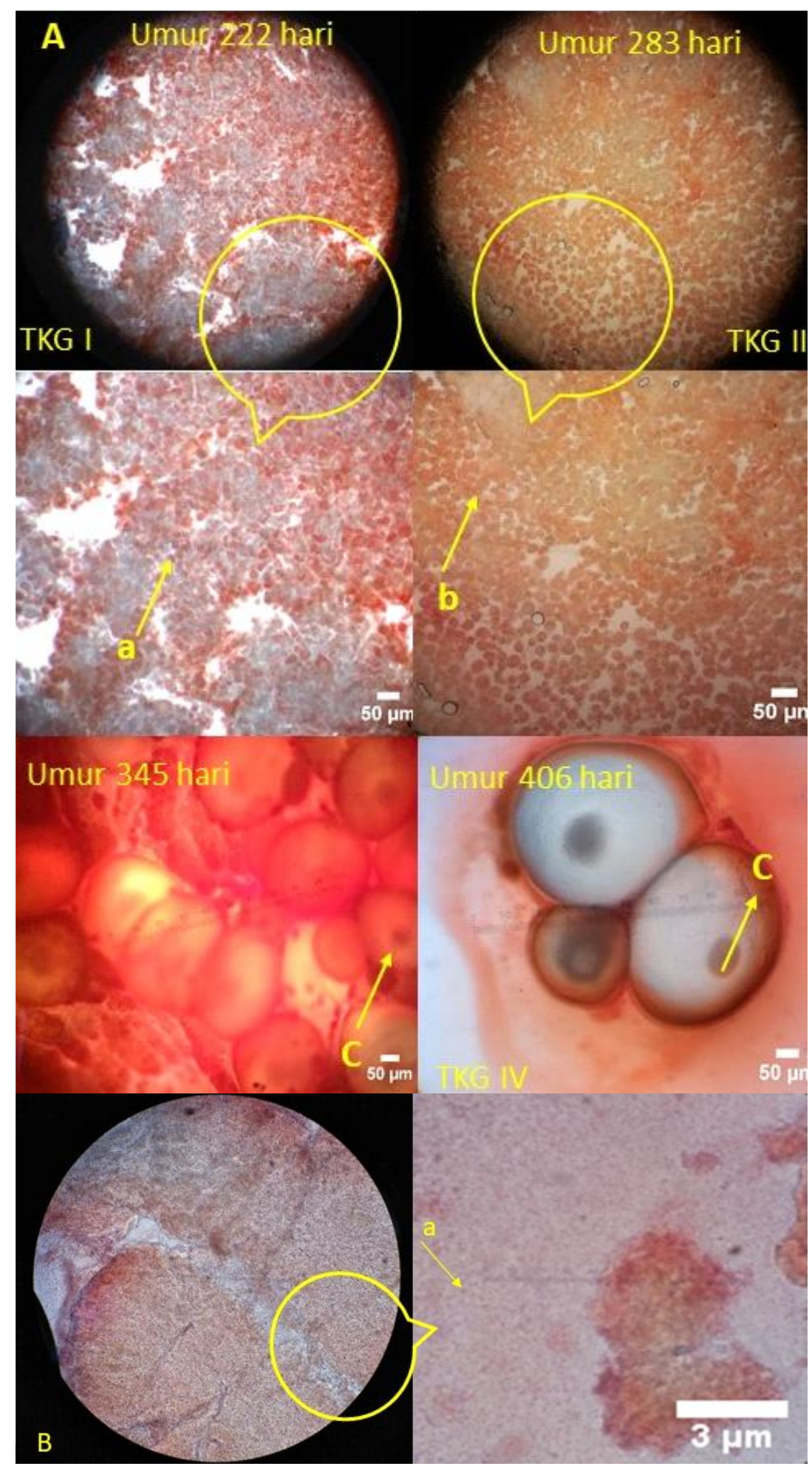

Gambar 7. A) Preparat gonad betina dengan pewarnaan acetocarmine; oogonia (a), oosit (b), dan nukleus (c); B) preparat gonad jantan; spermatozoa (a).

Figure 7. A) Female ovarian preparations with acetocarmine staining; 00gonia (a), oosit (b), and nukleus (c); B) Male testes preparations; spermatozoa (a). 
semua individu dan generasi berada dalam tahap perkembangan gonad yang sama. Sebagai produk hasil pemuliaan, perbedaan ini diduga akibat tidak semua individu dari setiap generasi mewarisi gen yang sama, kemudian adanya persaingan antar individu dalam lingkungan pemeliharaan sehingga hal ini dapat memicu tingkat stres yang berdampak terhadap hormonal. Menurut Grande \& Andersen (1990); Kime \& Nash (1999); Webb \& Doroshov (2011), perkembangan dan maturasi oosit ikan dipengaruhi oleh genetik, lingkungan, dan stres.

Dari preparat gonad betina ditemukan beberapa tingkat perkembangan oosit. Dalam satu bagian gonad di usia 406 hari terdapat beberapa tingkat oosit yaitu oosit dengan posisi inti di tengah, posisi inti sudah migrasi ke pinggir (GVBD) dan bahkan masih ada di antaranya yang belum terlihat inti sel (Gambar 5A). Berdasarkan hal tersebut, kondisi ini dapat menerangkan bahwa, tipe perkembangan gonad ikan baung termasuk tipe asynchronous. Adebiyi et al. (2011) menjelaskan, berdasarkan pemeriksaan histologi dan hasil yang diperoleh dari mikroskop elektron scanning mendukung fakta bahwa $\mathrm{H}$. nemurus memiliki tipe perkembangan gonad asynchronous. Fakta ini didukung dengan adanya data sebaran dan frekuensi diameter o osit yang beragam meski sebagian besar telah berada dalam tahap pematangan. Dengan demikian dapat disampaikan bahwa jenis pemijahan ikan baung bersifat partial spawner, didukung oleh pernyataan (Aryani et al., 2018) jenis pemijahan $H$. wyckii sama dengan $H$. Nemurus.

Diameter oosit merupakan ukuran pertumbuhan oosit, pengukuran dapat membantu kita untuk mendapatkan gambaran tingkat kematangan gonad, maturasi, dan penentuan masa pemijahan ikan. Semakin kecil rentang sebaran diameter oosit maka semakin seragam pula ukurannya, dan hal tersebut menandakan bahwa perkembangan gonad ikan semakin mendekati tahap maturasi (Tabel 2); (Gambar 8).

Hasil penelitian G-1 dan G-3 sudah berada dalam tahap pematangan dengan rata-rata diameter 1,11-1,13 $\mathrm{mm}$ dengan range indeks gonad somatik (IGS) 4,8\% $8,20 \%$ yang dicirikan dengan inti sel (germinal vesicel) telah muncul di bagian sentral dan GVBD. Dari penelitian lain dijelaskan bahwa rata-rata diameter oosit fase matur berkisar 450-1.000 5ØAßm (VI) dan 800-1.400 5ØAßm (VII) dengan range IGS 1,14 $\pm 0,87$ sampai dengan 7,06 $\pm 1,40$ (Adebiyi et al., 2011). Indeks gonad somatik (IGS) merupakan salah satu indikator penting dalam aktivitas reproduksi yang digunakan untuk menentukan maturasi gonad (Hojo et al., 2004). Nilai IGS meningkat seiring dengan bertambahnya bobot bobot ikan selama tahap perkembangan gonad, jadi besar kecilnya nilai IGS bergantung pada ukuran ikan. Dan nilai IGS dapat juga dipengaruhi oleh makanan (Çek \& Yilmaz, 2009).

\section{KESIMPULAN}

Tidak terdapat perbedaan pertumbuhan dan ukuran diameter telur yang signifikan di antara keturunan. Namun pertumbuhan terbaik dari ketiga keturunan adalah keturunan G-2 dengan rata-rara bobot jantan $212,82 \pm 0,01$, bo bot betina $211,62 \pm 26,44$; panjang jantan 16,5 $\pm 0,2$ dan panjang betina $16,7 \pm 1,11$. Laju pertumbuhan spesifik $0,48 \pm 0,01$ untuk ikan

Tabel 4. Diameter telur dan indeks kematangan gonad (IKG)

Table 4. Oocyte diameter and somatic gonad index (SGI)

\begin{tabular}{ccccc}
\hline $\begin{array}{c}\text { Umur (hari) } \\
\text { Age (days) }\end{array}$ & $\begin{array}{c}\text { Generasi } \\
\text { Generation }\end{array}$ & $\begin{array}{c}\text { Diameter telur } \\
\text { Egg diameters }(\mathbf{m m})\end{array}$ & $\begin{array}{c}\text { Bobot induk } \\
\text { Weight }(\mathbf{g})\end{array}$ & $\begin{array}{c}\text { Indeks kematangan gonad } \\
\text { Gonad maturity index (\%) }\end{array}$ \\
\hline \multirow{2}{*}{222} & 1 & gel (? 0.01) & $94.87 \pm 10.76$ & - \\
& 2 & gel (? 0.01) & $94.71 \pm 21.16$ & - \\
& 3 & gel (? 0.01) & $93.10 \pm 10.01$ & - \\
\cline { 2 - 5 } 283 & 1 & $0.025-0.05$ & $111.38 \pm 16.88$ & 0.31 \\
& 2 & $0.025-0.05$ & $97.50 \pm 0.04$ & 0.14 \\
& 3 & $0.025-0.05$ & $127.92 \pm 22.04$ & 0.18 \\
\cline { 2 - 5 } 345 & 1 & $0.59 \pm 0.24$ & $151.90 \pm 16.27$ & 0.54 \\
& 2 & $0.39 \pm 0.15$ & $208.86 \pm 56.99$ & 0.36 \\
& 3 & $0.48 \pm 0.15$ & $164.02 \pm 35.77$ & 0.34 \\
\hline \multirow{3}{*}{406} & 1 & $1.11 \pm 0.15^{\mathrm{a}}$ & $185.15 \pm 35.98$ & 8.20 \\
& 2 & $0.92 \pm 0.17^{\mathrm{a}}$ & $211.62 \pm 26.44$ & 0.98 \\
& 3 & $1.13 \pm 0.11^{\mathrm{a}}$ & $171.52 \pm 23.76$ & 4.8 \\
\hline
\end{tabular}

Keterangan (Note): a tidak beda nyata (not significantly different) 


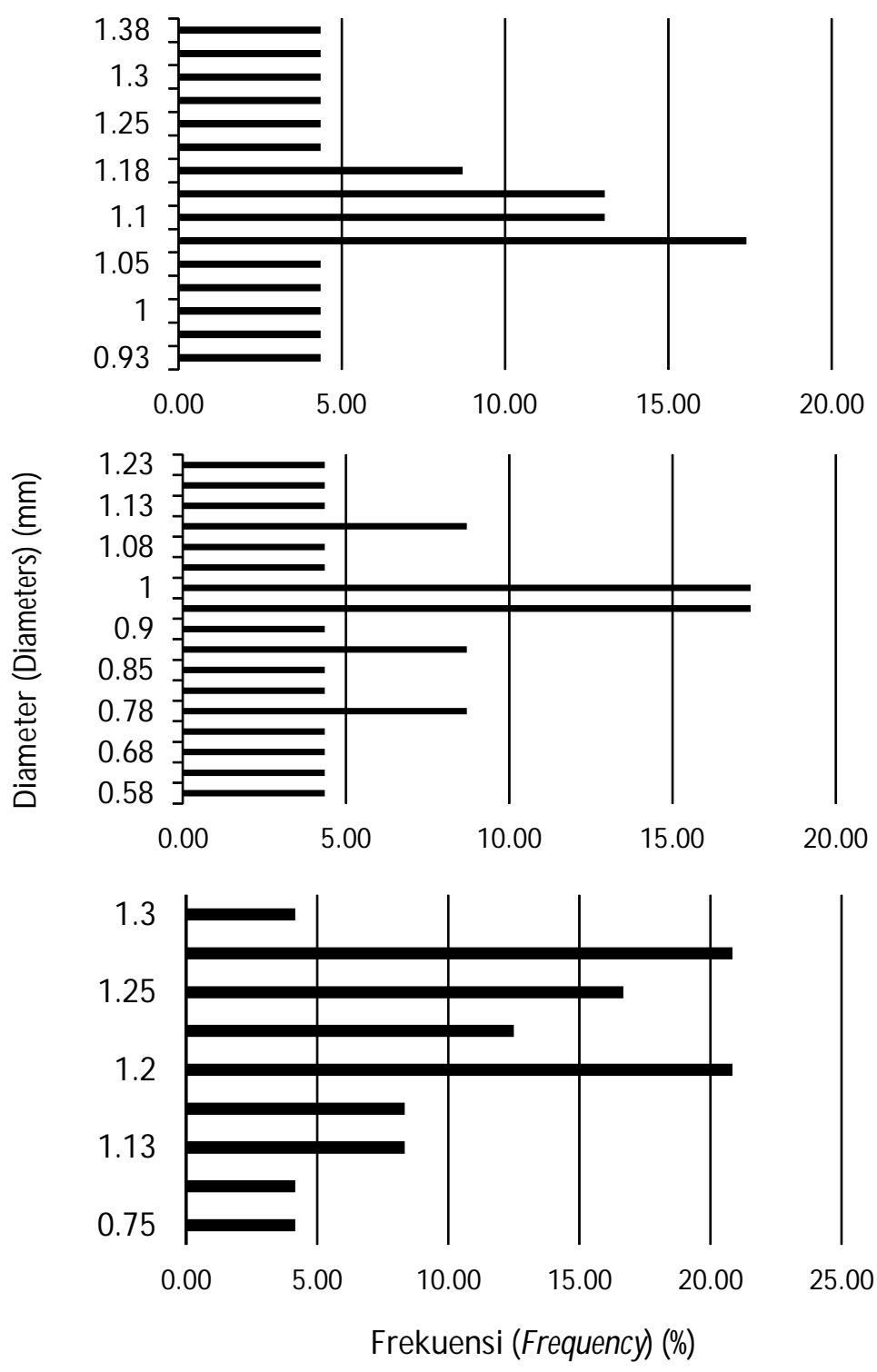

Gambar 8. Frekuensi distribusi diameter oosit.

Figure 8. Distribution frequency of oocyte diameter.

jantan dan 0,52 $\pm 0,12$ untuk ikan betina. Keturunan ke-2 (G-2) merupakan generasi terbaik untuk dijadikan kandidat budidaya. Pada umur yang sama dengan keturunan lainnya, G-2 memiliki ukuran badan yang lebih besar dan pertumbuhan gonad yang lebih lambat. Di mana rata-rata diameter telur pada usia $406 \mathrm{G}-1$ $(1,13 \pm 0,11 \mathrm{~mm}) ; \mathrm{G}-2(0,92 \pm 0,18 \mathrm{~mm}) ;$ dan G-3 $(1,11 \pm 0,10 \mathrm{~mm})$ dengan IKG G-1 (8,20\%); G-2 (0,98\%); dan G3 (4,8\%). Semakin lambat masa pertumbuhan gonad, semakin besar pula rentang waktu yang tersedia untuk pertumbuhan ikan tersebut dan semakin besar ukuran ikan saat pertama kali matang gonad maka, semakin besar ukuran gonad ikan. Dengan demikian semakin besar pula peluang untuk memperoleh fekunditas yang lebih banyak. Ukuran ikan tidak selalu berbanding lurus dengan ukuran gonad.

\section{UCAPAN TERIMA KASIH}

Penelitian ini dibiayai oleh DIPA 2018 BRPBATPP, Bogor. Penulis mengucapkan terima kasih kepada Saudara Heppy Aprilistianto dan Yudi Mulyadi yang telah membantu pelaksanaan penelitian ini.

\section{DAFTAR ACUAN}

Adebiyi, F.A., Siraj, S.S., Harmin, S.A., \& Christianus, A. (2011). Ovarian Development of a river catfish Hemibagrus nemurus (Valenciennes, 1840) in captivity. Journal Experimental Zoology, 315, 536-543. https://doi.org/10.3923/ajava.2013.237.246.

Aryani, N., Suharman, I., \& Syandri, H. (2018). Reproductive performance of asian catfish ( Hemibagrus wyckii Bleeker, 1858), a candidate species for aqua- 
culture. F1000Research, 1-14. https://doi.org/ 10.12688/f1000research.14746.1

Cek, S., Bromage, N., Randall, C., \& Rana, K. (2001). Oogenesis, hepatosomatic and gonadosomatic indexes, and sex ratio in rosy barb (Puntius conchonius)/ ? ehriban. Turkish Journal of Fisheries and Aquatic Sciences, 1, 33-41.

Çek, S. \& Yilmaz, E. (2009). The effect of varying dietary energy on gonad development at first sexual maturity of the sharptooth catfish (Clarias gariepinus Burchell, 1822). Aquaculture International, 17(6), 553-563.

Coward, K. \& Bromage, N.R. (1998). Histological classification of oocyte growth and the dynamics of ovarian recrudescence in tilapia zillii. Journal of Fish Biology, 53(2), 285-302.

Effendie, M.I. (1979). Metoda Biologi Perikanan. Yayasan Dewi Sri. Bogor, $112 \mathrm{hlm}$.

Farmbos. (2019). Harga ikan baung. Diakses pada 17 September 2019, dari https://farmbos.com/hargaikan-baung/\# z.

Grande, M. \& Andersen, S. (1990). Effect of two temperature regimes from a deep and a surface water release on early development of salmonids. Regulated Rivers Research \& Management, 5(4), 355360. https://doi.org/10.1002/rrr.3450050407.

Handoyo, B., Setiowibowo, C., \& Yustiran, Y. (2010). Cara mudah budi daya dan peluang bisnis ikan baung dan jelawat. Bogor: IPB Press.

Hewan, A. (2019). Daftar harga ikan baung di pasaran per kilo terbaru 2019. Diakses pada 17 September 2019, dari https://ahlihewan.com/harga-ikanbaung/.

Hojo, R.E.S., Santos, G.B., \& Bazzoli, N. (2004). Reproductive biology of Moenkhausia intermedia (Eigenmann) (Pisces, Characiformes) in Itumbiara Reservoir, Goiás, Brazil. Revista Brasileira de Zoologia, 21(3), 519-524. https://doi.org/10.1590/ S0101-81752004000300015.

Kime, D. \& Nash, J. (1999). Gamete viability as an indicator of reproductive endocrine disruption in fish. Science of The Total Environment, 233(1-3), 123-129.

Koç, N.D., Aytekin, Y., \& Yüce, R. (2008). Ovary maturation stages and histological investigation of ovary of the Zebrafish (Danio rerio). Brazilian Archives of Biology and Technology, 51(3), 513-522. ht t p s://doi .org/10.1590/S1516 89132008000300010 .
Krejszeff, S., Targoñska, K., Żarski, D., \& Kucharczyk, D. (2009). Domestication affects spawning of ide (Leuciscus idus) - preliminary study. Journal Aquaculture, 295(1-2), 145-147.

Kurniasih, T., Arifin, 0.Z., \& Marizal. (2006). Feminisasi nila (GIFT), Oreochromis sp. menggunakan hormon estradiol 17-â. Jurnal Perikanan (Journal of Fisheries Sciences), VII(1), 74-80.

Mesomya, W., Cuptapun, Y., Jittanoonta, P., Hengsawadi, D., Boonvisut, S., Huttayanon, P., \& Sriwatana, W. (2002). Nutritional evaluations of green catfish , Mystus nemurus. Kasetsart Journal, 36(October), 69-74.

Molen, S.Van Der, \& Matallanas, J. (2004). Reproductive biology of female Antarctic spiny plunderfish Harpagifer spinosus (Notothenioidei: Harpagiferidae), from Îles Crozet. Antarctic Science, 16(2), 99-105. https://doi.org/10.1017/ S0954102004001865.

Murtidjo, B.A. (2001). Beberapa Metode Pembenihan Ikan Air Tawar. Penerbit Kanasius, $108 \mathrm{hlm}$.

Nugroho, E., Hadie, W., \& Sudarto. (2003). Variasi genetik ikan baung, M ystus nemurus dari beberapa waduk di Jawa yang dianalisis dengan marker mitokondria D. loop. Jurnal Penelitian Perikanan Indonesia, 9(1), 1-5.

Ravaglia, M.A. \& Maggese, M.C. (2002). Oogenesis in the swamp eel Synbranchus marmoratus (Bloch, 1795) (Teleostei; Synbranchidae). Ovarian anatomy, stages of oocyte development and micropyle structure. Biocell, 26(3), 325-337.

Selman, K. \& Wallace, R.A. (1989). Cellular aspects of oocyte growth in teleosts. Zoological Science, 6, 211-231.

Solomon, F.N. \& Ramnarine, I.W. (2007). Reproductive biology of white mullet, Mugil curema (Valenciennes) in the Southern Caribbean. Fisheries Research, 88, 133-138. https://doi.org/ 10.1016/j.fishres.2007.06.024.

Subagja, J., Cahyanti, W., Nafiqoh, N., \& Arifin, 0.Z. (2015). Keragaan bioreproduksi dan pertumbuhan tiga populasi ikan baung. Jurnal Riset Akuakultur, 10(1), 25-32.

Webb, M.A.H. \& Doroshov, S.I. (2011). Importance of environmental endocrinology in fisheries management and aquaculture of sturgeons. General and Comparative Endocrinology, 170(2), 313-321.

Weatherley, A.H. \& Gill, H.S. (1987). The biology of fish growth (1st ed.). London: Academic Press. 